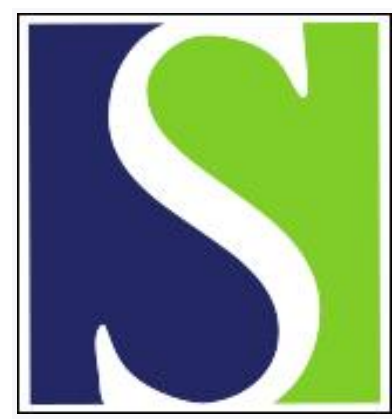

Scand J Work Environ Health 2002;28(6):402-410

https://doi.org/10.5271/sjweh.692

Issue date: Dec 2002

Exposure to carcinogenic air pollutants among policemen working close to traffic in an urban area

by Maître $A$, Soulat J-M, Masclet $P$, Stoklov $M$, Marquès $M$, de Gaudemaris R

Affiliation: Department of Occupational Medicine, EPSP-TIMC Laboratory, Grenoble University Medical School, Domaine de la Merci, FR-38 700 La Tronce, France. Anne.Maitre@ujf-grenoble.fr

Refers to the following texts of the Journal: 1999;25 suppl 3:33-39 1995;21(6):401-403

Key terms: aldehyde; automotive exhaust; carcinogenic air pollutant; environmental pollution; exposure; particulate matter; personal sampling; policeman; polycyclic aromatic hydrocarbon; traffic; urban area; volatile organic compound

This article in PubMed: www.ncbi.nlm.nih.gov/pubmed/12539800 


\title{
Exposure to carcinogenic air pollutants among policemen working close to traffic in an urban area
}

\author{
by Anne Maître, PhD, ${ }^{1}$ Jean-Marc Soulat, PhD, ${ }^{2}$ Pierre Masclet, MD, ${ }^{3}$ Muriel Stoklov, ${ }^{1}$ Marie Marquès, ${ }^{1}$ \\ Régis de Gaudemaris ${ }^{1}$
}

\begin{abstract}
Maître A, Soulat J-M, Masclet $P$, Stoklov M, Marquès M, de Gaudemaris R. Exposure to carcinogenic air pollutants among policemen working close to traffic in an urban area. Scand $J$ Work Environ Health 2002;28(6):402-410.
\end{abstract}

Objective This study evaluates individual airborne exposure to gaseous and particulate carcinogenic pollutants in a group of policemen working close to traffic in the center of Grenoble, France.

Methods Sixty-two personal active air samples were collected during the workshifts of eight policemen in summer and in winter during the occurrence of the thermal inversion phenomenon. Seventeen stationary air samples were monitored in the policemen's work area during the same period with the same sampling devices as used for the personal samples. The respirable particle concentration was determined using the gravimetric method. The concentrations of polycyclic aromatic hydrocarbons and aldehydes were measured with highperformance liquid chromatography with fluorimetric or ultraviolet detection. The benzene-toluene-xylene levels were determined with gas chromatography with flame ionization detection.

Results The median concentration of the personal samples for respirable particles was $55.5 \mu \mathrm{g} / \mathrm{m}^{3}$ in the summer and $124 \mu \mathrm{g} / \mathrm{m}^{3}$ in the winter. The corresponding values were 0.10 and $0.28 \mathrm{ng} / \mathrm{m}^{3}$ for benzo(a)pyrene, 14 and $21 \mu \mathrm{g} / \mathrm{m}^{3}$ for formaldehyde, and 10.5 and $23.5 \mu \mathrm{g} / \mathrm{m}^{3}$ for benzene. The median personal concentrations were equal to or higher than the corresponding stationary levels for both seasons. Compared with the concentration of aldehydes, the concentrations of respirable particles, polycyclic aromatic hydrocarbons, and benzene-toluenexylene appeared to show higher individual variability.

Conclusions The occupational exposure of policemen does not exceed any currently applicable occupational or medical exposure limits. Individual particulate levels should preferably be monitored in Grenoble in winter to avoid underestimations.

Key terms aldehyde, automotive exhaust, environmental pollution, particulate matter, personal sampling, polycyclic aromatic hydrocarbons, volatile organic compounds.

Better control of industrial emissions and an increase in road traffic have placed automotive exhaust as today's primary source of air pollution in most urban areas. It has been estimated that about $60 \%$ of the pollution released into urban areas is produced by diesel and gasoline engines (1). Vehicles are responsible for generating a large number of different pollutants present in the gas and particulate phase, and the main characteristic of diesel exhaust is the release of fine particles at a rate of about 10 to 20 times higher than that of gasoline-fueled vehicles (2).

Environmental studies have shown a correlation between particulate matter and adverse health effects, including the aggravation of illness in people with chronic respiratory disease and a rise in respiratory and cardiovascular mortality (3-5). However, other aspects of air pollution, such as carcinogenic effects, should be given consideration. The International Agency for Research

1 Department of Occupational Medicine, EPSP-TIMC (Environnement et Prédiction de la Santé des Populations) Laboratory, Grenoble University Medical School, La Tronche, France.

3 TEPE-LESAM (Transferts et Etudes des Polluants Environnementaux) Laboratory, ESIGEC, Le Bourget du Lac, France.

Reprint requests to: Dr Anne Maître, Department of Occupational Medicine, EPSP-TIMC Laboratory, Grenoble University Medical School, Domaine de la Merci, FR-38 700 La Tronche, France. [E-mail: Anne.Maitre@ ujf-grenoble.fr] 
on Cancer (IARC) concluded in 1989 that there was limited evidence of the carcinogenicity of diesel engine exhaust in humans and inadequate evidence of gasoline engine exhaust carcinogenicity (6). Some of the recent meta-analyses of published cohort and case-referent studies investigate the relationship between occupational diesel exhaust exposure and lung cancer $(7,8)$. The pooled smoking-adjusted relative risk for lung cancer was on the order of 1.3-1.5, but the extent to which urban air pollution contributed to this level remains unknown (9).

In the United States, the Environmental Protection Agency (EPA) has prioritized the following five carcinogenic air pollutants: benzene, formaldehyde, acetaldehyde, 1,3-butadiene, and polycyclic aromatic hydrocarbons (PAH) (10). The World Health Organization (WHO) has also included these five pollutants in its list of target atmospheric species $(11,12)$. Benzene has long been known to be a human carcinogen, and the strongest evidence links it with lymphohematopoietic cancers (13). Formaldehyde has been classified by IARC as a probable human carcinogen on the basis of evidence that excessive exposure is related to nasal and nasal-pharyngeal cancer (13). PAH that have been classified as probable or possible carcinogens by IARC (13) and the European Union (EU) (14) are those that are predominant in the particulate fraction $<2.5 \mu \mathrm{m}$. The lung seems to be the major target organ of PAH carcinogenicity. An increased risk is present in most industries, but results have been more consistent among workers with the most exposure (15).

Although low when compared with the risk estimates of specific occupational environments, this cancer risk estimate is of major public health concern because it encompasses urban populations working or living close to traffic zones. In order to assess the health risk linked to these compounds, it is necessary to acquire data on personal exposure. Combining air concentrations from stationary samples, time-activity information, and dispersion modeling has been commonly used to assess individual exposure in environmental studies $(16,17)$. However, conducting more accurate exposure assessments for greater epidemiologic data is a major challenge so that the extent of the increase in mortality risk due to cancer associated with air pollution can be better quantified (18). The airborne exposure to carcinogenic pollutants at the population or individual level is very difficult to assess, since the potential mechanisms of lung cancer include the small size and the chemical composition of particulate matter, in addition to different pollutants present in the gas phase (18-20). Unfortunately, personal exposure studies conducted in a group of people working close to traffic have generally focused either on particulate matter (21-23) or on volatile organic compounds (24-26).
The originality of the current study is the monitoring of individual airborne exposure to both gaseous and particulate carcinogenic pollutants among policemen during two seasons. In addition to particulate matter and volatile organic compounds, which are commonly measured at fixed monitoring stations in urban areas, we provided individual data on two groups of organic pollutants, aldehydes and PAH.

\section{Materials and methods}

\section{Study population and sampling strategy}

The study population was composed of eight nonsmoking policemen working outdoors on foot in the center of the city of Grenoble (population: 400000 ) located in the southeast of France. Each policeman completed a daily sampling questionnaire detailing the route covered during the workday and any possible technical problems encountered with the air monitoring devices.

Personal air sampling was carried out during the workshifts from 0900 to 1200 and from 1400 to 1800 . Each policeman wore a filter holder connected to a battery-operated sampling pump (SKC Ltd, Blandford Forum, United Kingdom), which was attached to the belt of the policeman's uniform. Stationary air samples were monitored in a busy square located in the center of Grenoble in the area where the policemen worked during the same period and with the same sampling devices as used for the personal samples. The stationary air monitors were positioned about 20 meters from and 1.50 meters above the roads. The flow rate of each sampling pump was calibrated using a Gilian debitmeter (Sensidyne Inc, Clearwater, United States) each morning and each afternoon before use and remeasured after the sampling at 1200 and 1800 . When the variation in the sampling rate was greater than $5 \%$, the sample was rejected. All the air sampling and analysis methods were carried out in accordance with French reference methods, as defined for industrial workplaces, and have been described in detail elsewhere (27).

Two sampling periods were selected, one in the summer and one in the winter. They lasted for four consecutive days in June or January, when winter thermal inversion in the city produced the worst weather conditions for air pollution. The concentrations of $\mathrm{PAH}$, benzene-toluene-xylenes (BTX), aldehydes, and respirable particles were monitored using individual and area-active sampling. Different sampling plans recording the PAH, BTX and aldehyde concentrations were taken for the two seasons to capture different types of variability. The individual spatial variability of the airborne levels was analyzed in the summer season. Eight personal 
samples and one stationary PAH sample were monitored the first day of the summer sampling period. Eight individual samples and one stationary sample of BTX were monitored the second day, whereas eight individual samples and one stationary sample of aldehydes were collected the third day (table 1). Moreover, the variability of the daily PAH, BTX, and aldehyde levels due to the thermal inversion setting was studied in the winter season. These three pollutant groups were monitored every day with one personal sample and one stationary sample. Thus eight personal samples and one stationary sample were monitored in the summer, whereas four personal samples and four stationary samples were collected in the winter season. Because of the poor sensitivity of the gravimetric method, respirable particles had to be collected during four consecutive days during the two seasons. Eight personal samples and one stationary particle sample were monitored in the summer, whereas four personal samples and one stationary sample were collected in the winter. Thus each policeman wore two sampling devices for the first 3 days of the summer sampling period and only one sampling device for the other days.

Meteorological data were obtained from the local automatic meteorological station. Traffic data and outdoor concentrations of particulate matter smaller than 10 micrometers in aerodynamic diameter $\left(\mathrm{PM}_{10}\right)$ were obtained at a fixed monitoring station located on a busy road in the city center. We gathered information concerning meteorological conditions, traffic density, and the $\mathrm{PM}_{10}$ concentrations on the sampling days.

\section{Sampling and analyses}

Respirable particles. Respirable particles (defined as the mass of particles that pass through a size selective ori- fice with a $50 \%$ collection efficiency at a cut-off aerodynamic diameter of $4 \mu \mathrm{m}$ ) were sampled using a cyclone (Arelco, Fontenay sous Bois, France) mounted on the inlet side of the filter holder. Each filter holder was loaded with a preweighed quartz fiber filter (Whatman International Ltd, Maidstone, United Kingdom), and the pump flow-rate to be drawn through the cyclone was set at $1.7 \mathrm{l} / \mathrm{min}$. After the sampling, the filter was removed from the holder and reweighed. For each sample, a control filter was weighed at the same time before and after the sampling. All the filters were acclimatized in the weighing room for 24 hours before being weighed. The change in weight of the controls was used to correct the mass on the exposed filter. The detection limit was $10 \mu \mathrm{g} / \mathrm{m}^{3}$ for a 28 -hour sampling period.

Particulate polycyclic aromatic hydrocarbons. Air samples were collected by trapping the total particulate $\mathrm{PAH}$ in Millipore Teflon filters (Millipore Headquarters, Bedford, United States) placed in a Swinnex polyethylene filter holder from Millipore, with a $4 \mathrm{~mm}$-diameter inlet air orifice. The filter flow rate was set at $1 \mathrm{l} / \mathrm{min}$. After the sampling, the filters were stored at $-20^{\circ} \mathrm{C}$ until the analysis. Ten milliliters of HPLC (high-performance liquid chromatography) grade dichloromethane was added to each filter and placed in a 15-milliliter glass tube. After ultrasonic extraction for 30 minutes, the filter was removed, and the volume of solvent was reduced to about 1 milliliter using a rotary evaporator at $30^{\circ} \mathrm{C}$. The concentrated fraction was filtered and then evaporated until almost dry. The residue was dissolved in 300 microliters of acetonitrile (HPLC grade). The analysis was carried out using a Waters HPLC system (Waters Corporate Headquarters, Milford, United States), which consisted of an autosampler (Wisp 700), two gradient pumps (Waters 501 and 510), a scanning fluorescence

Table 1. Personal and stationary sampling plan. $(A L D=$ aldehyde; $R P=$ respirable particles; $B T X=$ benzene-toluene- $x y l e n e s, P A H=$ polycyclic aromatic hydrocarbons)

\begin{tabular}{|c|c|c|c|c|c|c|c|c|c|}
\hline \multirow[t]{2}{*}{ Season } & \multicolumn{8}{|c|}{ Personal sampling } & \multirow{2}{*}{$\begin{array}{l}\text { Stationary } \\
\text { sampling }\end{array}$} \\
\hline & Subject 1 & Subject 2 & Subject 3 & Subject 4 & Subject 5 & Subject 6 & Subject 7 & Subject 8 & \\
\hline \multicolumn{10}{|l|}{ Summer } \\
\hline Day 1 & PAH1 \& RP1 & PAH2 \& RP2 & PAH3 \& RP3 & PAH4 \& RP4 & PAH5 \& RP5 & PAH6 \& RP6 & PAH7 \& RP7 & PAH8 \& RP8 & PAH9 \& RP9 \\
\hline Day 2 & BTX1 \& RP1 & BTX2 \& RP2 & BTX3 \& RP3 & BTX4 \& RP4 & BTX5 \& RP5 & BTX6 \& RP6 & BTX7 \& RP7 & BTX8 \& RP8 & BTX9 \& RP9 \\
\hline Day 3 & ALD1 \& RP1 & ALD2 \& RP2 & ALD3 \& RP3 & ALD4 \& RP4 & ALD5 \& RP5 & ALD6 \& RP6 & ALD7 \& RP7 & ALD8 \& RP8 & ALD9 \& RP9 \\
\hline Day 4 & RP1 & RP2 & RP3 & RP4 & RP5 & RP6 & RP7 & RP8 & RP9 \\
\hline \multicolumn{10}{|l|}{ Winter } \\
\hline Day 1 & PAH1 & BTX1 & ALD1 & RP1 & RP2 & RP3 & RP4 & - & PAH5 - BTX5 \& ALD5 - RP5 \\
\hline Day 2 & PAH2 & BTX2 & ALD2 & RP1 & RP2 & RP3 & RP4 & - & PAH6 - BTX6 \& ALD6 - RP \\
\hline Day 3 & РАН3 & BTX3 & ALD3 & RP1 & RP2 & RP3 & RP4 & - & PAH7 - BTX7 \& ALD7 - RP5 \\
\hline Day 4 & PAH4 & BTX4 & ALD4 & RP1 & RP2 & RP3 & RP4 & - & PAH8-BTX8 \& ALD8 - RP5 \\
\hline
\end{tabular}


detector (Waters 474) and a HPLC system manager (Maxima 820). A C18 Supelco (Sigma-Aldrich Chimie, Lyon, France) reversed phase column (LC-PAH, $250 \mathrm{~m} \times$ $3-\mathrm{mm}$ inner diameter) was maintained at $30^{\circ} \mathrm{C}$ with a Waters column temperature-control module. The elution was made with a gradient of acetonitrile and water. The PAH were identified by means of six pairs of excitation and emission wavelengths to obtain the best possible selectivity and sensitivity. A quantitative analysis was carried out using external standards with a certified Supelco PAH calibration mix. The following nine PAH were quantified: fluoranthene, pyrene, benzo(a)anthracene, chrysene, benzo(b)fluoranthene, benzo(k)fluoranthene, benzo(a)pyrene, dibenzo(a,h)anthracene, and benzo(ghi)perylene. The detection limit was $0.3 \mathrm{ng} / \mathrm{m}^{3}$ for fluoranthene and pyrene, $0.06 \mathrm{ng} / \mathrm{m}^{3}$ for benzo(a)anthracene and chrysene, $0.2 \mathrm{ng} / \mathrm{m}^{3}$ for benzo(b)fluoranthene, $0.02 \mathrm{ng} / \mathrm{m}^{3}$ for benzo(k)fluoranthene, $0.1 \mathrm{ng} / \mathrm{m}^{3}$ for benzo(a)pyrene and dibenzo(a,h)anthracene, and $0.4 \mathrm{ng} / \mathrm{m}^{3}$ for benzo(ghi)perylene for an 8-hour sampling period.

Benzene-toluene-xylenes. BTX were collected on Supelco adsorbent tubes with 100 and 50 milligrams of activated coconut charcoal (20/40 mesh) in the front and backup section, respectively. The flow rate of the sampling pump was calibrated to $100 \mathrm{ml} / \mathrm{min}$. The tubes were stored at $4^{\circ} \mathrm{C}$ until the analysis 1 week later. The BTX were extracted from both charcoal traps using 1 milliliter of carbon disulfide. The analysis was performed using a Hewlett-Packard (Aligent Technologies, Massy, France) gas chromatograph (5890 series II) with flame ionization detection and a JW analytical column (DBwax $60 \mathrm{~m} \times 0.25$ - $\mathrm{mm}$ inner diameter). A temperature program of 50 to $200^{\circ} \mathrm{C}$ was used. Blank tubes were also analyzed, as were compound standard solutions within the carbon disulfide concentration range of $0.05-$ $10 \mu \mathrm{g} / \mathrm{ml}$ that was used for the calibration. The detection limit was higher than $1 \mu \mathrm{g} / \mathrm{m}^{3}$ for an 8 -hour sampling period for the three compounds. Our laboratory participated in the quality assurance program organized by the French National Institute for Research and Safety and was accredited for benzene sampling and analysis by the French Department of Labor.

Aldehydes. Aldehydes were collected with 2,4-dinitrophenylhydrazine-coated silica in a 2-milliliter Supelco cartridge. The sampling flow rate was set at $11 / \mathrm{min}$. After the derivative was extracted using 2.5 milliliters of acetonitrile, the analysis was carried out using a Waters liquid chromatograph with ultraviolet detection (Lambdamax 481) and a Supelco analytical column (Supelcosil LC18; $150 \mathrm{~m} \times 4.6-\mathrm{mm}$ inner diameter). The elution was made with a gradient of acetonitrile and water. The detection limits for formaldehyde, acetalde- hyde, and acroleine were $0.07,0.06$, and $0.008 \mu \mathrm{g} / \mathrm{m}^{3}$, respectively, for an 8-hour sampling period.

\section{Data analysis}

The statistical analysis was conducted using the SPSS for Windows ${ }^{\mathrm{TM}}$ statistical software program (SPSS Inc, Chicago, Illinois, United States). The Mann-Whitney (U) two-independent-samples nonparametric test was used for comparing the personal data from the two seasons.

\section{Results}

\section{Sampling strategy}

The policemen were chosen to wear the sampling devices on the basis of their work schedules. In addition, the number of policemen who work in town in the winter is lower than in the summer, and the number of personal samples was limited by this restriction. The activity patterns of the policemen were comparable for the two sampling periods. They enforced law and order or verified parking meters in the city center of Grenoble (population 400000 ) near the square where the stationary samples were being collected.

A factor limiting the sample number was the poor sensitivity of the gravimetric method, which required the subjects to wear sampling devices for four consecutive days. This constraint explained the loss of one respirable particle sample in the winter. Moreover, one stationary BTX sample and one personal aldehyde sample were rejected before the analysis due to a variation greater than $5 \%$ in the sampling rate.

\section{Meteorological conditions and traffic density}

Hourly temperature means, hourly means of the wind speed, daily pressure means, and traffic density are presented for the two sampling periods in table 2 . The meteorological conditions in the summer were anticyclonic with a tendency towards storms. Temperatures reached a maximum of $33^{\circ} \mathrm{C}$ in the early afternoon. Wind speed was lower in the winter than in the summer, ranging from 0 to $1.3 \mathrm{~m} / \mathrm{s}$ and from 0.1 to $3.2 \mathrm{~m} / \mathrm{s}$, respectively. The drop in temperature recorded on the third day was due to rainfall in the evening of the second day. In the winter, the thermal inversion that was present for almost a week before the sampling period persisted during the week of testing. There was no wind, and it was cold in the center of the city. These conditions were favorable for the accumulation of airborne pollutants close to the ground. 
Table 2. Meteorological and traffic data and the levels of particulate matter smaller than $10 \mu \mathrm{m}$ in aerodynamic diameter $\left(\mathrm{PM}_{10}\right)$ recorded during the two sampling periods.

\begin{tabular}{|c|c|c|c|c|c|c|c|c|c|c|}
\hline \multirow[t]{2}{*}{ Sampling day } & \multicolumn{2}{|c|}{$\begin{array}{l}\text { Hourly mean } \\
\text { temperature }\left({ }^{\circ} \mathrm{C}\right)\end{array}$} & \multicolumn{2}{|c|}{$\begin{array}{l}\text { Hourly mean wind } \\
\text { speed }(\mathrm{m} / \mathrm{s})\end{array}$} & \multicolumn{2}{|c|}{$\begin{array}{l}\text { Daily mean atmospheric } \\
\text { pressure }(\mathrm{hPa})^{\text {a }}\end{array}$} & \multicolumn{2}{|c|}{$\begin{array}{l}\text { Daily mean of the hourly } \\
\text { automotive means }(\mathrm{N})\end{array}$} & \multicolumn{2}{|c|}{$\begin{array}{l}\text { Daily } \mathrm{PM}_{10} \text { levels } \\
\qquad\left(\mu \mathrm{g} / \mathrm{m}^{3}\right)\end{array}$} \\
\hline & Summer & Winter & Summer & Summer & Winter & Winter & Summer & Winter & Summer & Winter \\
\hline \multicolumn{11}{|l|}{ Day 1} \\
\hline 0900 & 24 & -5 & 0.1 & 0 & & & & & & \\
\hline 1400 & 32 & 6 & 1.4 & 0.1 & 1029 & 1030 & 5031 & 5079 & 40 & 77 \\
\hline 1800 & 30 & -2 & 2.4 & 0.5 & & & & & & \\
\hline \multicolumn{11}{|l|}{ Day 2} \\
\hline 0900 & 25 & -4 & 0.1 & 0 & & & & & & \\
\hline 1400 & 33 & 8 & 1.4 & 0 & 1029 & 1030 & 5022 & 5009 & 43 & 89 \\
\hline 1800 & 28 & 0 & 2.4 & 0.3 & & & & & & \\
\hline \multicolumn{11}{|l|}{ Day 3} \\
\hline 0900 & 19 & -4 & 2.5 & 0 & & & & & & \\
\hline 1400 & 21 & 9 & 0.3 & 0 & 1028 & 1028 & 5035 & 4645 & 44 & 76 \\
\hline 1800 & 23 & 0 & 3.2 & 1.3 & & & & & & \\
\hline \multicolumn{11}{|l|}{ Day $4 ?$} \\
\hline 0900 & 20 & -3 & 1.8 & 0.2 & & & & & & \\
\hline 1400 & 27 & 4 & 1.5 & 0.1 & 1028 & 1024 & 5267 & 4878 & 46 & 98 \\
\hline 1800 & 24 & 1 & 2.2 & 0.7 & & & & & & \\
\hline
\end{tabular}

a The atmospheric pressure data have been adjusted to sea level.

Table 3. Airborne concentrations of the pollutants monitored during the two workshift sampling periods. $(\mathrm{ND}=$ not detectable, BaP $=$ benxo(a)pyrene, $\mathrm{PAH}=$ polycyclic aromatic hydrocarbons, $\mathrm{PAHc}=$ carcinogenic polycyclic aromatic hydrocarbons, BTX $=$ benzenetoluene-xylenes)

\begin{tabular}{|c|c|c|c|c|c|c|c|c|c|c|c|c|c|c|c|c|c|}
\hline & \multicolumn{7}{|c|}{ Summer } & \multicolumn{10}{|c|}{ Winter } \\
\hline & \multicolumn{5}{|c|}{ Personal sampling } & \multicolumn{2}{|c|}{$\begin{array}{l}\text { Stationary } \\
\text { sampling }\end{array}$} & \multicolumn{5}{|c|}{ Personal sampling } & \multicolumn{5}{|c|}{ Stationary sampling } \\
\hline & N & Median & Mean & SD & Range & $\mathrm{N}$ & Mean & N & Median & Mean & SD & Range & N & Median & Mean & $\mathrm{SD}$ & Range \\
\hline $\begin{array}{l}\text { Respirable } \\
\text { particles }\left(\mu \mathrm{g} / \mathrm{m}^{3}\right)\end{array}$ & 8 & 55.5 & 58.1 & 23.6 & $33-97$ & 1 & 25 & 3 & 124 & 123 & 6.2 & $115-130$ & 1 & & 124 & & \\
\hline $\operatorname{BaP}\left(n g / m^{3}\right)$ & 8 & 0.10 & 0.18 & 0.19 & ND-0.52 & 1 & 0.03 & 4 & 0.28 & 1.44 & 2.10 & $0.13-5.08$ & 4 & 0.14 & 1.25 & 2.00 & ND-4.71 \\
\hline $\mathrm{PAHc}^{\mathrm{a}}\left(\mathrm{ng} / \mathrm{m}^{3}\right)$ & 8 & 0.50 & 0.86 & 0.73 & $0.2-2.11$ & 1 & 0.37 & 4 & 1.19 & 6.52 & 10.75 & $0.49-22.62$ & 4 & 1.56 & 7.2 & 12.2 & $0.06-25.42$ \\
\hline $\mathrm{PAH}\left(\mathrm{ng} / \mathrm{m}^{3}\right)$ & 8 & 3.89 & 4.17 & 2.4 & $1.75-8.11$ & 1 & 2.19 & 4 & 13.14 & 27.31 & 27.1 & $8.88-74.1$ & 4 & 12.26 & 26.53 & 29.05 & $5.01-76.58$ \\
\hline Benzene $\left(\mu \mathrm{g} / \mathrm{m}^{3}\right)$ & 8 & 10.5 & 12.6 & 5.2 & $7-24$ & 1 & 9.5 & 4 & 23.5 & 23.7 & 5.8 & 18-30 & 3 & 17 & 16.7 & 1.2 & 15-18 \\
\hline Toluene $\left(\mu \mathrm{g} / \mathrm{m}^{3}\right)$ & 8 & 34 & 40.6 & 20.6 & $18-89$ & 1 & 24.5 & 4 & 94.5 & 94.5 & 24.5 & $69-120$ & 3 & 52 & 53 & 4.6 & $48-59$ \\
\hline Xylene $\left(\mu \mathrm{g} / \mathrm{m}^{3}\right)$ & 8 & 26.5 & 35.4 & 22.1 & $20-91$ & 1 & 19.5 & 4 & 74 & 72.3 & 16.1 & $52-89$ & 3 & 39 & 37.7 & 6.6 & $29-45$ \\
\hline BTX $\left(\mu \mathrm{g} / \mathrm{m}^{3}\right)$ & 8 & 71.5 & 88.6 & 47.1 & $47-204$ & 1 & 53.5 & 4 & 192 & 190.5 & 46.2 & $139-239$ & 3 & 108 & 107 & 12.3 & $92-12$ \\
\hline $\begin{array}{l}\text { Formaldehyde } \\
\left(\mu \mathrm{g} / \mathrm{m}^{3}\right)\end{array}$ & 8 & 14 & 14.6 & 2.4 & $11-19$ & 1 & 8 & 3 & 21 & 22.7 & 3.9 & $19-28$ & 4 & 17.5 & 17 & 1.2 & $15-18$ \\
\hline $\begin{array}{l}\text { Acetaldehyde } \\
\left(\mu \mathrm{g} / \mathrm{m}^{3}\right)\end{array}$ & 8 & 9.5 & 9.25 & 1.64 & $6-12$ & 1 & 4 & 3 & 17 & 18.7 & 3.9 & $15-24$ & 4 & 10.5 & 10.2 & 0.8 & $9-11$ \\
\hline $\begin{array}{l}\text { Aldehydes } \\
\left(\mu \mathrm{g} / \mathrm{m}^{3}\right)\end{array}$ & 8 & 23.7 & 24 & 3.8 & $17-29$ & 1 & 12 & 3 & 38 & 41.3 & 7.7 & $34-52$ & 4 & 28 & 27.3 & 2.1 & $24-29$ \\
\hline
\end{tabular}

a PAHc include benzo(a)anthracene, chrysene, benzo(b)fluoranthene, benzo(k)fluoranthene, benzo(a)pyrene, dibenzo(a,h)anthracene.

Traffic density was comparable during the two sampling periods, with a decrease of less than $4 \%$ during the winter. The mean of the number of vehicles per sampling period was 5089 (SD 103) and 4903 (SD 165) during the summer and winter, respectively.

\section{Air concentrations}

Respirable particles. The respirable particle concentrations determined using personal and stationary sampling in the two seasons are given in table 3. The personal 
concentrations monitored in the summer varied by a factor of 1 to 3 , and they were always higher than the stationary levels. The personal samples collected in the winter were in the same range as the stationary levels, but they were significantly higher than the personal levels measured during the summer $(\mathrm{P}<0.05)$. The same differences were found between the two seasons for the stationary respirable particle levels, and for the $\mathrm{PM}_{10}$ levels recorded by a fixed ambient air monitoring station located in the city center (table 2).

Particulate polycyclic aromatic hydrocarbons. The particulate PAH concentrations that were monitored using personal and stationary sampling are presented in table 3 for both seasons. The sum of the carcinogenic PAH, classified into "group 2" by the European Union, includes benzo(a)anthracene, benzo(b)fluoranthene, benzo(k)fluoranthene, benzo(a)pyrene, chrysene, and dibenzo(a,h)anthracene. The personal carcinogenic PAH concentrations varied by a factor of 1 to 10 in the summer, when the benzo(a)pyrene levels were not detectable up to $0.52 \mathrm{ng} / \mathrm{m}^{3}$. The personal median concentrations were comparable to the stationary levels for the two seasons. While the personal PAH levels monitored in the winter were significantly higher than those measured during the summer $(\mathrm{P}<0.05)$, the observed differences between the personal benzo(a)pyrene and carcinogenic PAH levels did not reach a statistically significant level. Pyrene and fluoranthene represented $70 \%$ of the total particulate PAH in the summer and $80 \%$ in the winter. Whereas the relative abundance of pyrene decreased significantly by $15 \%$ in the summer $(\mathrm{P}<0.05)$, that of all the other PAH increased.

Benzene-toluene-xylenes. The BTX concentrations monitored using personal and stationary sampling are presented for the two seasons in table 3 . The benzene concentrations of the personal samples varied by a factor of 1 to 3 in the summer, when their median concentration was comparable to the stationary level. The personal concentrations were significantly lower than those measured during the winter $(\mathrm{P}<0.05)$. Benzene represented around $13 \%$ of the total BTX for both seasons.

Aldehydes. The aldehyde concentrations monitored using personal and stationary sampling are presented in table 3 for both seasons. The formaldehyde and acetaldehyde concentrations varied in the personal samples by a factor of 1 to 2 in the summer. Their median concentrations were higher than those of the corresponding stationary levels. The concentrations of the personal samples were significantly lower than those measured during the winter for the two compounds $(\mathrm{P}<0.05)$. The median concentrations of formaldehyde and acetaldehyde in the personal and stationary samples were com- parable. The relative abundance of formaldehyde was around $60 \%$ of the total aldehydes and was comparable between the two seasons.

\section{Discussion}

Conducting a study on individual exposure levels in a professional environment using active air sampling is always difficult, time consuming, and expensive, and these factors explain the small sample size of this type of study $(21,22)$, in comparison with the large number of environmental studies estimating personal exposure from measurements made by central fixed site monitors $(16,17)$. The policemen included in our study can be considered representative of the many urban workers (postal workers, newspaper vendors, and the like) exposed to traffic at work, but extrapolation to the total daily exposure of city dwellers, who spend only $6 \%$ of their time outdoors (17), is more difficult $(26,28)$.

The respirable particle levels of the policemen in our study are comparable for the winter season with those of traffic wardens working in Aberdeen (22). However, a comparison of the measurements reported in different studies should be done with caution since samples may be collected using different sampling devices and for different sampling periods (29). Thus higher particulate concentrations (mean $440 \mu \mathrm{g} / \mathrm{m}^{3}$ ) were reported for traffic policemen when total dust was collected (24). On the other hand, lower personal levels (mean $40 \mu \mathrm{g} / \mathrm{m}^{3}$ ) were found for postal workers and gardeners in the winter season when the samples were monitored using a $\mathrm{PM}_{2.5}$ sampling filter holder (21). In addition, if a finer particle fraction is to be trapped, allowance must be made for the fact that personal levels are monitored over 24 hours, whereas the samples from our study were collected only during one workshift. Our personal levels agree with the respirable particulate air concentrations measured in major European cities (50-100 $\left.\mu \mathrm{g} / \mathrm{m}^{3}\right)(11)$, particularly in Paris $\left(75-150 \mu \mathrm{g} / \mathrm{m}^{3}\right)(30)$, where they are 2.5 to 5 times the Swedish urban background level (29). Diesel exhaust contributes heavily to ambient air particles in France, where the diesel share of the automotive market is $45 \%$ (31). These particulate levels are somewhat lower than the corresponding values for occupational groups directly exposed to diesel exhaust emissions, such as railroad, bus, and truck drivers (1).

The benzo(a)pyrene exposure of policemen in Grenoble was comparable with that of nonsmoking policemen working in Teplice in the winter season (21). However, higher levels were reported when smokers were included in the study population $(21,23)$. Although the polyethylene filter holders used in our study are less electrostatic than the polystyrene closed-face Millipore 
cassette generally used in France, loss of dust on the internal walls of the sampling devices may lead to an underestimation of occupational exposure levels $(32,33)$. All the personal benzo(a)pyrene concentrations measured in the urban area were significantly lower than the French recommended occupational exposure limit of $150 \mathrm{ng} / \mathrm{m}^{3}$. These concentrations are in accordance with the ambient air levels recorded in Europe during recent years, which ranged from 0.1 to $20 \mathrm{ng} / \mathrm{m}^{3}(34,35)$. Air temperature plays an important role, modulating particulate pollutant air levels and the composition of the organic matter adsorbed on air particles (36). The shift of this distribution towards the particulate phase at low temperatures is one of the explanations for the increase in the relative abundance found for pyrene during the winter season $(37,38)$.

The exposure levels of municipal policemen in the city of Grenoble are half that of other policemen working in the center of Paris or in large Italian cities, whether it be for benzene, toluene, or xylenes $(24,25,39)$. The inclusion of smokers in these studies may partially explain the difference. Indeed, whereas the exposure of nonsmokers to benzene is mainly linked to vehicles, $90 \%$ of that of smokers comes from cigarettes (28). Furthermore, the differences in meteorological conditions, sampling and analytical procedures, and, above all, traffic density between cities contribute to these pollution levels. Thus the atmospheric concentrations measured in Paris (benzene 10-37 $\mu \mathrm{g} / \mathrm{m}^{3}$ ) are higher than those found in English, American or Scandinavian cities (28, 40-42). In a recent study, lower personal levels (mean $9.3 \mu \mathrm{g} / \mathrm{m}^{3}$ ) than those found in our study were reported for traffic policemen working in Rome (26). The authors explained this drop in urban benzene pollution, compared with that found in earlier studies, by the reduction of the benzene content of gasoline.

The levels of exposure to aldehydes and, above all, formaldehyde of the municipal policemen working in the city center of Grenoble are among the highest found in European cities, even other French cities. Indeed, the mean concentrations of outdoor formaldehyde have, in general, been observed to be in the range of $1-20 \mu \mathrm{g} / \mathrm{m}^{3}$ (34). The high levels in Grenoble can possibly be explained by the fact that all of the city buses run on biofuel. Numerous studies have indicated a rise in aldehydes in the exhaust gases of vehicles that run on biofuel, whether it be diesters or alcoholic compounds (16, 43). These compounds are not routinely measured in urban air, and thus few data exist on the ambient concentration of aldehydes. Formaldehyde is the compound found in the highest concentrations, followed by acetaldehyde, and the concentrations of acroleine are very low. This aldehyde profile is traditionally found in studies in which formaldehyde represents over $50 \%$ of all aldehydes emitted in exhaust gases $(16,34)$. When per- sonal levels are monitored with passive samplers over 24 hours, the formaldehyde concentrations are comparable with those of our study because the contribution from the outdoor environment is very low in comparison with that from indoor exposure, as the sources of these compounds are primarily found in the habitat (44). However, because of the problem of contamination, passive samplers need further study evaluating their use in monitoring low levels of aldehyde in the environment (45).

Although the number of data was limited, the personal levels were inclined to be higher than concentrations determined from stationary samples. This tendency has already been reported by large-scale studies (21, $22,28,38,46)$. Furthermore, the airborne pollutant levels monitored in the summer were lower than those found in the winter, although the activity patterns of policemen are similar for both seasons. These differences, which have been reported each year by the Grenoble air pollution monitoring network for particulate pollutants, cannot be explained by the variations in traffic density, but, rather, by factors linked to meteorological conditions $(16,38)$. Thermal inversion, which produces the worst weather conditions for air pollution, is a common situation found in the winter since Grenoble is a city located in a valley basin surrounded by three mountain massifs measuring between 2000 and 3000 meters high. These results illustrate the difficulty to assess individual exposure to carcinogenic pollutants. In addition to the particles and organic compounds measured in our study, some carcinogenic metals present in the environment (such as arsenic and cadmium) should be monitored to assess exposure to carcinogenic pollutants. In order to take all air pollutants, as well as all the defense mechanisms of each person into account, recent studies have used biological monitoring measuring covalent reaction products of the carcinogen with DNA (deoxyribonucleic acid) or cytogenetic effects. Although high levels of DNA adducts or cytogenetic effects have been detected among policemen working in urban areas $(21,47)$, these results have not been found in other studies (23). The wide range of individual exposure found in our study suggests that at least some of the variation between persons observed in biomarker studies may be due to variations in human exposure rather than to genetic or metabolic differences alone.

Despite the limitations and the difficulties discussed, airborne monitoring remains the only method that enables primary sources of pollutant emission to be highlighted, and therefore, with respect to prevention, it should be given priority. Monitoring individual exposure is important not only for the collection of information concerning the actual distribution of individual exposure within a population group, but also for the formulation and validation of environmental exposure models defined by equations. 


\section{Acknowledgments}

This study was supported by the Rhône-Alpes Region, the Ministry of Labor, and the Cancer Research Agency. We are grateful to Ms Sylvette Liaudy for the documentational research and to Nicolas Vigier of the Grenoble air pollution monitoring network for traffic data, meteorological data, and $\mathrm{PM}_{10}$ concentrations.

\section{References}

1. World Health Organization (WHO). Diesel fuel and exhaust emissions. Geneva: WHO, 1996. Environmental health criteria, vol 171.

2. Westerholm R, Egebäck KE. Exhaust emissions from lightand heavy-duty vehicles: chemical composition, impact of exhaust after treatment, and fuel parameters. Environ Health Perspect 1994;102:13-23.

3. Lebowitz MD. Epidemiological studies of the respiratory effects of air pollution. Eur Respir J 1996;9:1029-54.

4. Künzli N, Kaiser R, Medina S, Studnicka M, Chanel O, Filiger P, et al. Public-health impact of outdoor and trafficrelated air pollution: a European assessment. Lancet 2000; 356:795-801.

5. Nyberg F, Pershagen G. Epidemiologic studies on the health effects of ambient particulate air pollution. Scand J Work Environ Heath 2000;26 suppl 1:49-94.

6. International Agency for Research on Cancer (IARC). Diesel and gasoline engine exhausts and some nitroarenes. Lyon: IARC, 1989. IARC monographs on the evaluation of the carcinogenic risks to humans, vol 46.

7. Bhatia R, Lopipero P, Smith AH. Diesel exhaust exposure and lung cancer. Epidemiology 1998;9:84-91.

8. Lipsett M, Campleman S. Occupational exposure to diesel exhaust and lung cancer: a meta-analysis. Am J Public Health 1999;89:1009-17.

9. Hemminki K, Pershagen G. Cancer risk of air pollution: epidemiological evidence. Environ Health Perspect 1994; 102:187-92.

10. Environmental Protection Agency (EPA). Motor vehicle related toxic study. Cincinnati (OH): EPA, 1993. EPA-R-93005 .

11. Lubkert-Alcamo B. The update and revision of the 1987 WHO air quality guidelines. Pollut Atmos 1994;144:95-101.

12. Union Européenne. Directive $N^{\circ} 96 / 62 / C E$ du Conseil du 27 septembre 1996 concernant l'évaluation et la gestion de la qualité de l'air ambiant. J Offic CE 1996; L296 du 21 novembre.

13. International Agency for Research on Cancer (IARC). Overall evaluations of carcinogenicity to humans. Lyon: IARC, 2000. As evaluated in IARC monographs volumes 1-77.

14. Institut National de Recherche et Sécurité. Produits chimiques cancérogènes, mutagènes, toxiques pour la reproduction. Cah Notes Doc 1997;169:547-73. Update of December 1998 and additional of December 2000:1-4.

15. Boffetta P, Jourenkova N, Gustavsson P. Cancer risk from occupational and environmental exposure to polycyclic aromatic hydrocarbons. Cancer Causes Control 1997;8:444-72.

16. Boström CE, Almen J, Steen B, Westerholm R. Human exposure to urban air pollution. Environ Health Perspect 1994;
102:39-47.

17. Özkaynak H. Exposure assessment. In: Holgate ST, Samet JM, Koren HS, Maynard RL, editors. Air pollution and health. London: Academic Press, 1999;149-62.

18. Pershagen G, Simonato L. Epidemiological evidence on air pollution and cancer. In: Tomatis L, editor. Indoor and outdoor air pollution and human cancer. Berlin: Springer, 1993:135-48. Monographs of the European School of Oncology.

19. Nikula KJ, Snipes MB, Barr EB, Griffith WC, Henderson $\mathrm{RF}$, Mauderly JL. Influence of particle-associated organic compounds on the carcinogenicity of diesel exhaust. In: Mohr U, Dungworth DL, Mauderly JL, Oberdörster G, editors. Toxic and carcinogenic effects of solid particles in the respiratory tract. Washington (DC): International Life Science Institute Press, 1994:565-8.

20. Rudell B, Blomberg A, Helleday R, Ledin MC, Lundback B, Sternjerb N, et al. Bronchoalveolar inflammation after exposure to diesel exhaust: comparison between unfiltered and particle trap filtered exhaust. Occup Environ Med 1999; 56:527-34.

21. Binkova B, Lewtas J, Miskova I, Lenicek J, Sram R. DNA adducts and personal air monitoring of carcinogenic polycyclic aromatic hydrocarbons in an environmentally exposed population. Carcinogenesis 1995;16:1037-46.

22. Watt M, Godden D, Cherrie J, Seaton A. Individual exposure to particulate air pollution and its relevance to thresholds for health effects: a study of traffic wardens. Occup Environ Med 1995;52:790-2.

23. Merlo F, Bolognesi C, Peluso M, Valerio F, Abbondandolo A, Puntoni R. Airborne levels of polycyclic aromatic hydrocarbons: ${ }^{32} \mathrm{P}-$ postlabeling DNA adducts and micronuclei in white blood cells from traffic police workers and urban residents. J Environ Pathol Toxicol Oncol 1997;16:157-62.

24. Priante E, Schiavon I, Boschi G, Gori G, Bartolucci GB, Soave $\mathrm{C}$, et al. Urban air pollutant exposure among traffic policemen. Med Lav 1996;87:314-22.

25. Bugajny C, Delaunay C, Vieillard H, Petit-Coviaux F, Coiron $\mathrm{C}$, Squinazi F, et al. Effets de la pollution atmosphérique d'origine automobile sur la santé des policiers affectés à la circulation à Paris. Pollut Atmos 1999;161:109-22.

26. Crebelli R, Tomei F, Zijno A, Ghittori S, Imbriani M, Gamberale D, et al. Exposure to benzene in urban workers: environmental and biological monitoring of traffic police in Rome. Occup Environ Med 2001;58:165-71.

27. Maître A, Stoklov M. Places et limites des prélèvements atmosphériques et des indicateurs biologiques d'exposition. In: Encyclopédie Médicale et Chirurgicale; Toxicologie Pathologie Professionnelle. Paris: Elsevier,1999. 16001-B10:9.

28. Wallace L. Environmental exposure to benzene: an update. Environ Health Perspect 1996;104:1129-36.

29. Areskoug H. Particles in the ambient atmosphere. Scand J Work Environ Heath 2000;26 suppl 1:5-22.

30. Stroebel R. La qualité de l'air en 1990 dans les zones urbaines, industrielles, et rurales françaises. Pollut Atmos 1991;131:389-403.

31. Société Française de Santé Publique (SFSP). La pollution atmosphérique d'origine automobile et la santé publique. Bilan de 15 ans de recherche internationale. Vandoeuvre-lèsNancy: SFSP, 1996. Collection Santé et Société vol 4.

32. Demange M, Gendre JC, Herve-Bazin B, Carton B, Peltier A. Aerosol evaluation difficulties due to particle deposition on filter holder inner walls. Ann Occup Hyg 1990;34(4):399-403. 
33. Liden G, Juringe L, Gudmundsson A. Workplace validation of a laboratory evaluation test of samplers for inhalable and total dust. J Aerosol Sci 2000;31(2):199-219.

34. World Health Organization (WHO). Air quality guidelines for Europe. Copenhagen: WHO, 1987. WHO regional publications, European series, vol 23.

35. Hemminki K, Veidebaum T. Environmental pollution and human exposure to polycyclic aromatic hydrocarbons in the east Baltic region. Scand J Work Environ Heath 1999;25 suppl 3:33-9.

36. Crebelli R, Fuselli S, Baldassarri LT, Ziemacki G, Carere A, Benigni R. Genotoxicity of urban air particulate matter: correlations between mutagenicity data, airborne micropollutants, and meteorological parameters. Int J Environ Health Res 1995;5:19-34.

37. Wild SR, Jones KC. Polycyclic aromatic hydrocarbons in the United Kingdom environment: a preliminary source inventory and budget. Environ Pollut 1995;88:91-108.

38. Menichini E. Urban air pollution by polycyclic aromatic hydrocarbons: levels and sources of variability. Sci Total Environ 1992;116:109-15.

39. Buratti M, Pellegrino O, Fustinoni S, Colombi A. Biological monitoring of environmental benzene exposure in traffic wardens. Med Lav 1997;88:208-19.

40. Chan CC, Spengler JD, Özkaynak H, Lefkopoulou M. Commuter exposures to VOCs in Boston, Massachusetts. J Air Waste Manage Assoc 1991;12:1594-600.

41. Coursimault A, Donati J, Viellard. La pollution automobile due aux hydrocarbures aromatiques monocycliques à Paris. Sci Total Environ 1995;169:17-23.

42. Van Wijnen JH, Verhoeff AP, Jans HWA, Van Bruggen M. The exposure of cyclists, car drivers and pedestrians to traffic-related air pollutants. Int Arch Occup Environ Health 1995;67:87-193.

43. Mittelbach M, Trittardt P, Junek H. Diesel fuel derived from vegetable oils. II: emission tests using rape oil methyl ester. Energy Agric 1985;3:207-15.

44. Gonzales-Flesca N, Cicolella A, Bates M, Bastin E. Pilot study of personal, indoor and outdoor exposure to benzene, formaldehyde and acetaldehyde. Environ Sci Pollut Res 1999;6(2):95-102.

45. Noble JS, Strang CR, Michael PR. A comparison of active and passive sampling devices for full-shift and short-term monitoring of formaldehyde. Am Ind Hyg Assoc J 1993; 54(12):723-32.

46. Biggeri A, Barbone F, Lagazio C, Bovenzi M, Stanta G. Air pollution and lung cancer in Trieste, Italy: spatial analysis of risk as a function of distance from sources. Environ Health Perspect 1996;104:750-4.

47. Chandrasekaran R, Samy PL, Murthy PB. Increased sister chromatid exchange (SCE) frequencies in lymphocytes from traffic policemen exposed to automobile exhaust pollution. Hum Exp Toxicol 1996;15:301-4.

Received for publication: 21 September 2001 